\title{
The advantage of chimeric antigen receptor $T$ cell therapy in pediatric acute lymphoblastic leukemia with E2A-HLF fusion gene positivity: a case series
}

\author{
Shuiyan $\mathrm{Wu}^{1,2 \#}$, Jun $\mathrm{Lu}^{2 \#}$, Dongni Su${ }^{1}$, Fan Yang ${ }^{2}$, Yongping Zhang ${ }^{2}$, Shaoyan $\mathrm{Hu}^{2}$ \\ ${ }^{1}$ Department of Intensive Care Unit, Children's Hospital of Soochow University, Suzhou, China; ${ }^{2}$ Department of Hematology \& Oncology, \\ Children's Hospital of Soochow University, Suzhou, China \\ \#These authors contributed equally to this work. \\ Correspondence to: Shaoyan Hu. Department of Hematology \& Oncology, Children's Hospital of Soochow University, Suzhou, Jiangsu, China. \\ Email: doctor1219@163.com.
}

\begin{abstract}
The E2A-HLF fusion gene is a very poor biomarker in acute lymphoblastic leukemia (ALL) because of its high relapse risk, even with the most intensive chemotherapy and hematopoietic stem cell transplantation (HSCT). Here, we analyzed four cases diagnosed with E2A-HLF fusion gene-positive B-ALL and treated with the CCCG-ALL-2015 protocol based on high-risk stratification from Jun 2017 to May 2020 retrospectively. Three cases (Case 1,2,3) were insensitive to conventional therapy and inhibitors with high-level MRD on days 19 and 46, but they all achieved complete remission at the molecular level with Chimeric Antigen Receptor (CAR) T cell therapy regardless of primary resistance or recurrence. Although remission was initially achieved for Case 4, chemotherapeutics was not sensitive after recurrence. However, CAR-T cell therapy gave him the chance to obtain complement remission again. Cytokine release syndrome (CRS) with fever, chills, acute kidney injury, hypotension and capillary leak syndrome and CAR-T related encephalopathy syndrome (CRE) with seizures and encephaledema occurred after CAR-T cell therapy, but symptoms disappeared with effective intensive care. Overall, CAR-T cell therapy enabled the patients to achieve complement remission with controllable adverse events. Our results indicated that CAR-T cell therapy is a feasible and effective therapy for patients with E2A-HLF-positive B-ALL and prompted the authors to report these cases.
\end{abstract}

Keywords: E2A-HLF; pediatric; acute lymphoblastic leukemia (ALL); CAR-T cells therapy; case series

Submitted Oct 05, 2020. Accepted for publication Dec 23, 2020.

doi: $10.21037 / \mathrm{tp}-20-323$

View this article at: http://dx.doi.org/10.21037/tp-20-323

\section{Introduction}

The incidence of the E2A-HLF fusion gene in ALL is approximately $1 \%$ and is caused by the $\mathrm{t}(17 ; 19)$ (q22;p13) translocation to form a mutant fusion protein that is thought to play a role in pathogenesis $(1,2)$. Moreover, this gene was identified as a poor prognostic indicator in B-ALL patients $(3,4)$. Glover et al. reported a patient who benefited from dasatinib combined with chemotherapy (5). Fischer and Frismantas held the view that venetoclax was an effective inhibitor to cure this disease $(6,7)$. In addition, a report showed that haploidentical transplantation followed by intensive donor lymphocyte infusions (DLIs) led to remission in a patient (8). However, CAR-T cell therapy applied in this kind of disease has rarely been reported. In this report, we described 4 cases diagnosed with E2A-HLFpositive B-ALL that showed a rapid response to CAR-T cell therapy. We present the following cases in accordance with the AME Case Series Checklist (available at http://dx.doi. org/10.21037/tp-20-323).

\section{Methods}

All procedures performed in studies involving human 
participants were in accordance with the ethical standards of the institutional and/or national research committee(s) and with the Helsinki Declaration (as revised in 2013). Written informed consent was obtained from the patients' parents/ guardians. Four patients went to receive CAR-T cell therapy as a clinical trial which was approved by the ethics committee of Children's Hospital of Soochow University [2016004].

This study is a case series. Four cases diagnosed with E2A-HLF fusion gene-positive B-ALL and treated with the CCCG-ALL-2015 protocol (9) based on high-risk stratification were retrospectively collected from Jun 2017 to May 2020 in Children's Hospital of Soochow University.

\section{Results}

Case 1 showed a poor response to the standard induction therapy of prednisolone, vincristine, cyclophosphamide, daunorubicin, and L-asparaginase (VDLD) with the CCCG-ALL 2015 protocol as the high-risk group (9). On day 19 , the minimal residual disease (MRD) was $1.64 \times 10^{-1}$ by flow cytometry. After consolidation therapy with cyclophosphamide, cytarabine, and mercaptopurine (CAM), the MRD was still $7.6 \times 10^{-2}$ on day 46 . Then, reinduction therapy was started with vincristine, mitoxantrone, and dexamethasone (MOP). Following this salvage therapy, bone marrow evaluation showed that the MRD was $3.2 \times 10^{-1}$. Therefore, CAR-T cell therapy $\left(1 \times 10^{7}\right.$ cells $/ \mathrm{kg}$, infusion, 3 times, from himself) was complimented. There were no adverse reactions after the first two infusions, and only a mild fever was observed after the third time. After one week, bone marrow evaluation presented molecularlevel remission, with an MRD less than $1 \times 10^{-4}$. On day 40 after CAR- $T$ cell therapy, the patient then received 5/10 mismatched haploidentical transplantation from his father on the basis of remission. Seven months later, the patient relapsed, with $65 \%$ blasts and $7.68 \times 10^{-1} \mathrm{MRD}$. CAR-T cell therapy $\left(1 \times 10^{7}\right.$ cells $/ \mathrm{kg}$, infusion, from his father) was used again to ease the tumor burden. There were incidences of hypotension, chills, acute kidney injury and increased body temperature after CAR-T cell therapy. Tocilizumab, norepinephrine and continuous renal replacement were used to relieve these symptoms. Ten days later, he achieved remission, and then, umbilical cord blood transplantation was carried out. After successful transplantation, there was a time when molecular remission was achieved, but unfortunately, recurrence occurred again in the later stage, even combined with DLI, venetoclax and dasatinib therapy, and lung GVHD appeared after transplantation. Finally, the patient died of respiratory failure on day 570 after diagnosis.

Case 2 employed venetoclax orally following VDLD from the CCCG-ALL 2015 protocol. Bone evaluation on days 19 and 46 showed MRD levels of $3.09 \times 10^{-1}$ and $3.82 \times 10^{-3}$, respectively. CAR-T cell therapy $\left(1 \times 10^{7}\right.$ cells $/ \mathrm{kg}$, infusion, two doses, from himself) was used for reinduction, replacing any further intensive chemotherapy. No reaction was found following the first dose. Four days later, the second dose was employed, with resulting fever and hand tremble, but the symptoms disappeared with tocilizumab. The bone marrow was evaluated again one week later and showed fusion gene negativity and an MRD less than $1 \times 10^{-4}$. On day 60 after CAR-T cell therapy, the patient was given HSCT, and his father was the donor with HLA 7/10 matched. The treatment succeeded, and the patient has survived for 110 days since diagnosis.

Case 3 was treated with the CCCG-ALL-2015 protocol as well. The MRD was $1.69 \times 10^{-2}$ and $1.04 \times 10^{-2}$ on days 19 and 46, respectively. The E2A-HLF fusion gene was still positive. The patient was treated with CAR-T cell therapy $\left(1 \times 10^{7}\right.$ cells $/ \mathrm{kg}$, infusion, from himself $)$ instead of consolidation chemotherapy. CRS with fever, hypotension and capillary leak syndrome and CRE with seizures and encephaledema occurred after therapy. Symptoms disappeared with effective intensive care. The bone marrow was showed that the patient achieved CR at day 7 after CAR-T cell therapy. To date, he has survived for 240 days since diagnosis.

Case 4 was enrolled in the same protocol. VDLD was conducted two weeks later because of disseminated intravascular coagulation recurrence. The MRD was less than $1 \times 10^{-4}$ after induction therapy and remained negative after consolidation chemotherapy with CAM and high-dose MTX. Unfortunately, on day 177 of the maintenance treatment phase, although the MRD was less than $1 \times 10^{-4}$, the fusion gene turned positive, with elevated blasts. The patient was given reinduction therapy with cyclophosphamide, idarubicin, vindesine and dexamethasone (CIOP) and reconsolidation therapy with CAM. However, the MRD was still at a high level $\left(1.1 \times 10^{-3}\right)$. The patient was given CAR-T cell therapy $\left(5 \times 10^{6}\right.$ cells $/ \mathrm{kg}$, twice, infusion, from himself), and at day 14 , the MRD and fusion gene turned negative again. On day 70 after CAR-T cell therapy, the disease relapsed and failed to be treated with vindesine, idarubicin, cyclophosphamide, L-asparaginase, and dexamethasone (VDCLP). The patient survived for 378 days after CAR-T cell therapy and died of 


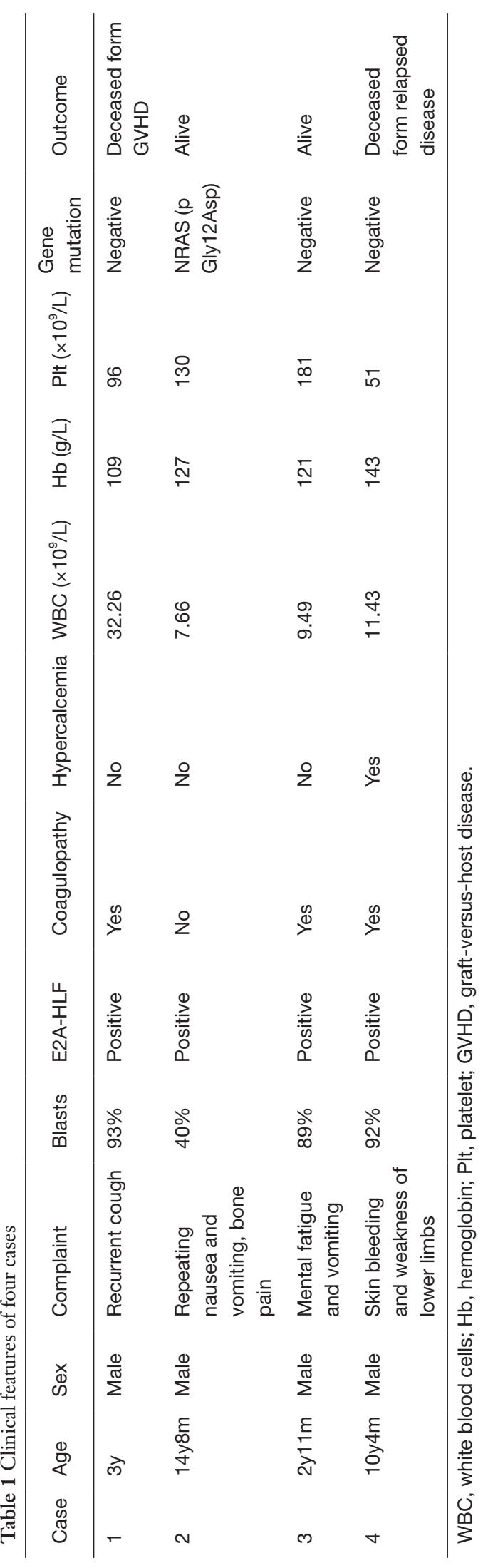

resistant disease.

The clinical features of the four cases are summarized in Table 1. The pretreatment regimens for CAR-T cell therapy in the 4 cases are illustrated in Figure 1. The variation of the E2A-HLF fusion gene and MRD levels are also illustrated in Figure 2. Table S1 shows the changes in cytokines after CAR-T cell therapy and intensive supportive care in these patients.

\section{Discussion}

The four cases were diagnosed with E2A-HLF fusion genepositive B-ALL and treated with the CCCG-ALL-2015 protocol based on high-risk stratification. Overall, 3 of 4 patients did not achieve effective molecular remission with conventional chemotherapy and inhibitors, but they all achieved complete remission at the molecular level with CAR-T cell therapy regardless of primary resistance or recurrence. One patient (Case 3) did not obtain remission by induction and consolidation therapy, but he achieved molecular remission after CAR-T cell therapy, with 4 months of disease-free survival, which indicated the efficacy of CAR-T cell therapy (10). This was the first successful case in which remission was achieved only via this remedy. Another patient (Case 2), who first adopted conventional chemotherapeutics combined with venetoclax, was not cured, which was in contrast with previous studies $(6,7,11)$. Fischer $e t a l$. reported that such patients were sensitive to anthracyclines, glucocorticoids and venetoclax through drug sensitivity (7). Jason et al. also found that dasatinib combined with intravenous chemotherapeutics resulted in a patient achieving 9 years of disease-free survival, which suggested that dasatinib may be beneficial (5). In addition, DLI is regarded as an effective treatment (8). However, for Case 1, although the patient endured all these therapies, unfortunately, he did not obtain a good outcome. Although remission was initially achieved for Case 4, chemotherapeutic therapy was not sensitive after recurrence. However, CAR-T cell therapy gave him the chance to obtain complement remission again.

Currently, CAR-T cell therapy has been successfully applied to treat relapsed/refractory disease (12). However, the use of this therapy in B-ALL with $t(17 ; 19)(\mathrm{q} 22 ; \mathrm{p} 13)$ translocation has rarely been reported. It is well known that this kind of disease has a poor outcome because of its high resistance to chemotherapeutics, inhibitors and even HSCT. Compared to chemotherapy, CAR-T cell therapy has shown remarkable activity against B-ALL, with high 

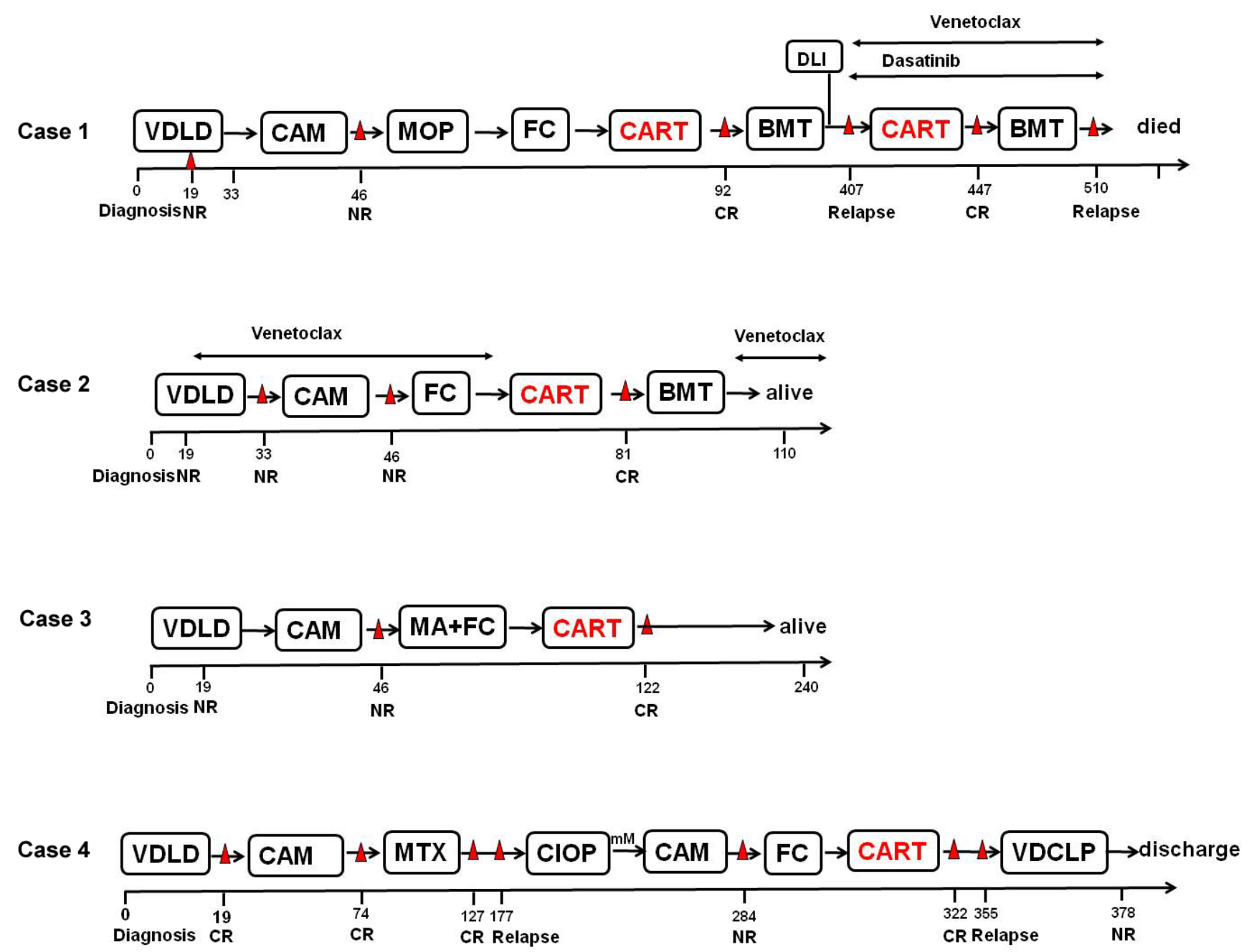

\section{Days elapsed}

Figure 1 Flow chart of treatment protocol with four cases. VDLD, prednisolone, vincristine, cyclophosphamide, daunorubicin, and L-asparaginase; CAM, cyclophosphamide, cytarabine, and mercaptopurine ; MOP, vincristine, mitoxantrone, dexamethasone; FC, cyclophosphamide, fludarabine; MA+FC, cytarabine, mitoxantrone, cyclophosphamide, fludarabine; CIOP, cyclophosphamide, idarubicin, vindesine, dexamethasone; VDCLP, vindesine, idarubicin, cyclophosphamide, L-asparaginase, dexamethasone; BMT, bone marrow transplant; CART, CAR-T cells therapy; DLI, donor lymphocyte infusions; MTX, methotrexate.

complete response rates and controlled CRS and CRE, which resembled the results of previous reports of adult and pediatric ALL patients $(10,13)$. However, the limitation of this study is that we only have four cases and more samples should be analyzed in further to validate this conclusion.

\section{Conclusions}

CAR-T cell therapy used for E2A-HLF fusion genepositive ALL proved to be a promising therapy, and this targeted immune therapy should be considered in such patients. 
A

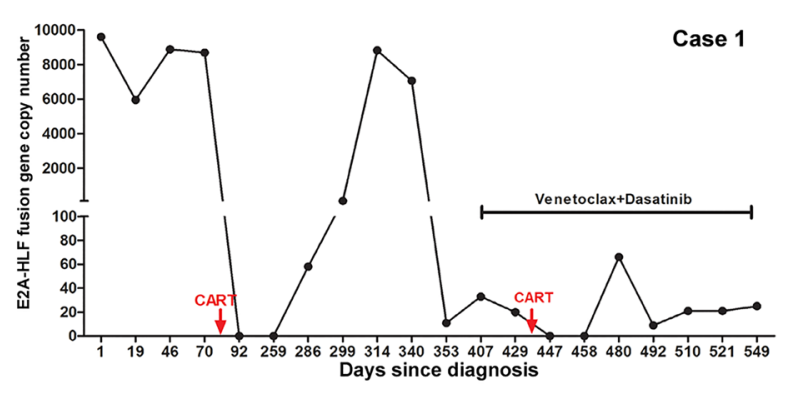

B

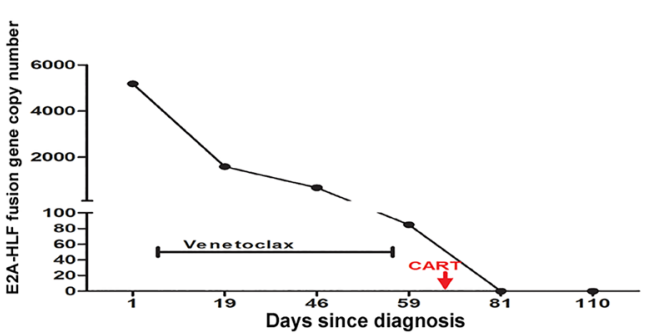

C:

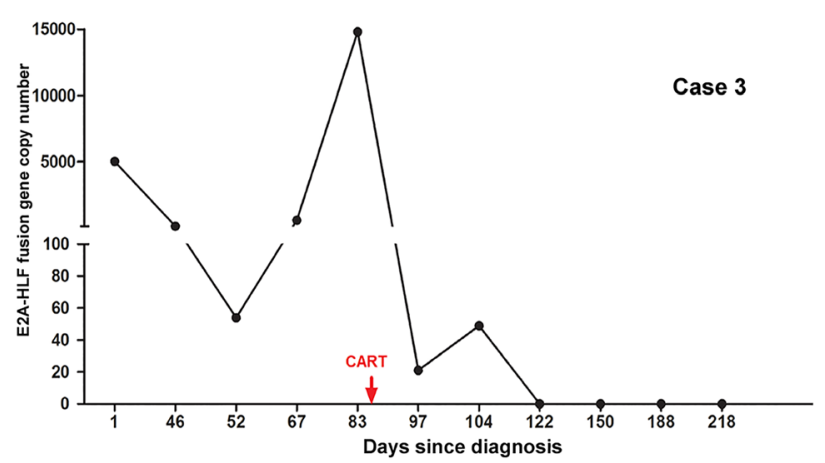

D-

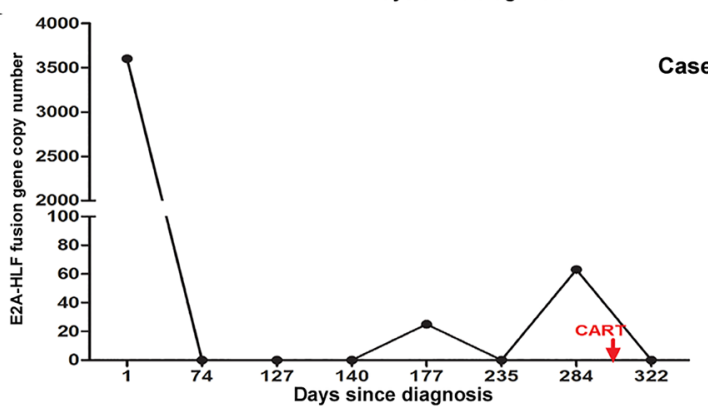

Case 2
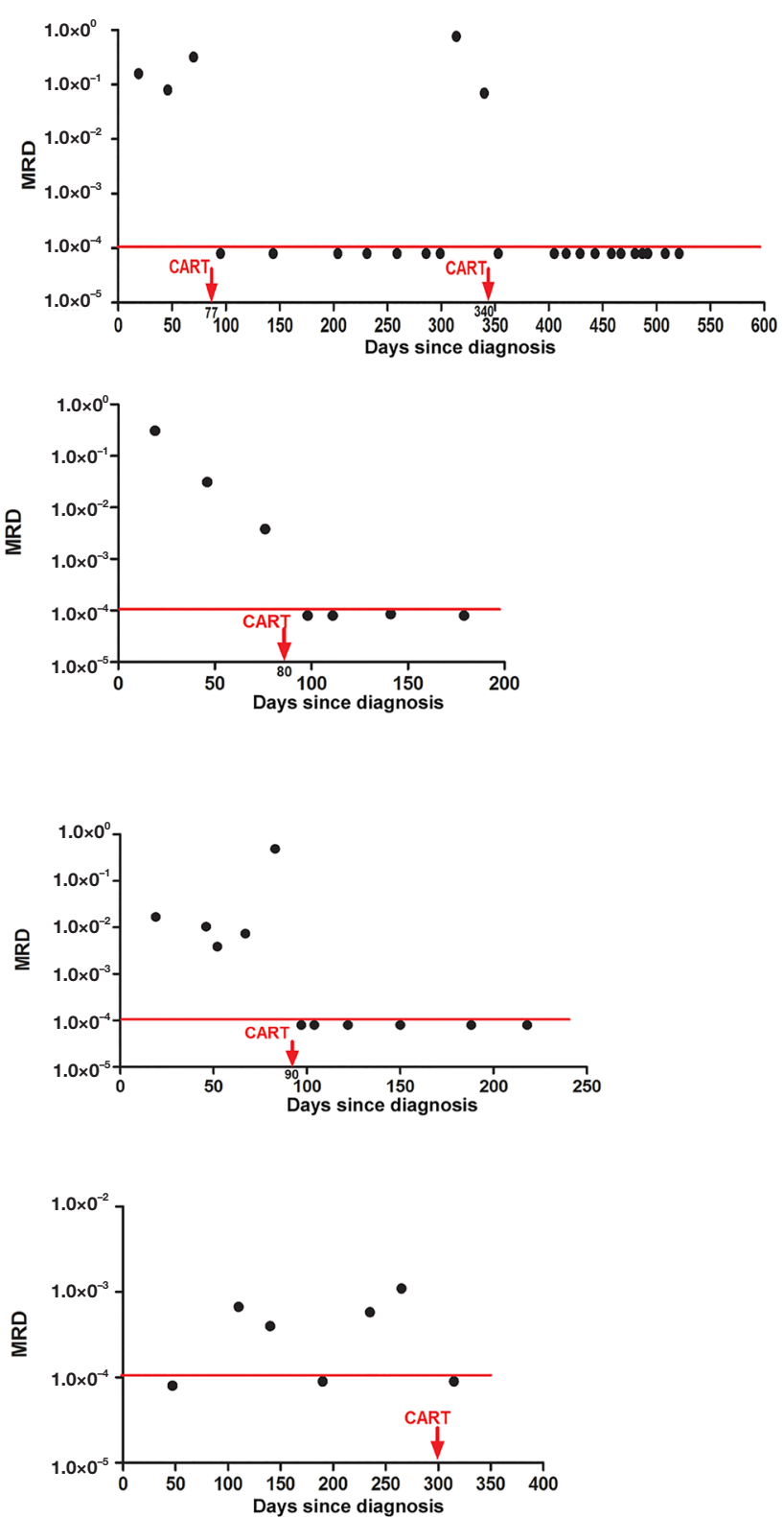

Figure 2 Variation of E2A-HLF fusion gene and MRD in four patients. CART, Chimeric Antigen Receptor (CAR) T cell therapy; MRD, minimal residual disease.

\section{Acknowledgments}

Funding: Suzhou Science and Technology Development Project (SYS 201757) and Natural science Foundation of Jiangsu Higher Education Institutions of China (18KJB320022).

\section{Footnote}

Reporting Checklist: The authors have completed the AME Case Series Checklist. Available at http://dx.doi. org/10.21037/tp-20-323 
Peer Review File: Available at http://dx.doi.org/10.21037/tp20-323

Conflicts of Interest: All authors have completed the ICMJE uniform disclosure form (available at http://dx.doi. org/10.21037/tp-20-323). The authors have no conflicts of interest to declare.

Ethical Statement: The authors are accountable for all aspects of the work in ensuring that questions related to the accuracy or integrity of any part of the work are appropriately investigated and resolved. All procedures performed in studies involving human participants were in accordance with the ethical standards of the institutional and/or national research committee(s) and with the Helsinki Declaration (as revised in 2013). Written informed consent was obtained from the patients' parents/guardians.

Open Access Statement: This is an Open Access article distributed in accordance with the Creative Commons Attribution-NonCommercial-NoDerivs 4.0 International License (CC BY-NC-ND 4.0), which permits the noncommercial replication and distribution of the article with the strict proviso that no changes or edits are made and the original work is properly cited (including links to both the formal publication through the relevant DOI and the license). See: https://creativecommons.org/licenses/by-nc-nd/4.0/.

\section{References}

1. Hunger SP. Chromosomal translocations involving the E2A gene in acute lymphoblastic leukemia: clinical features and molecular pathogenesis. Blood 1996;87:1211-24.

2. Hunger SP, Devaraj PE, Foroni L, et al. Two types of genomic rearrangements create alternative E2A-HLF fusion proteins in $\mathrm{t}(17 ; 19)-\mathrm{ALL}$. Blood 1994;83:2970-7.

3. Inukai T, Hirose K, Inaba T, et al. Hypercalcemia in childhood acute lymphoblastic leukemia: frequent implication of parathyroid hormone-related peptide and E2A-HLF from translocation 17;19. Leukemia

Cite this article as: $\mathrm{Wu} \mathrm{S,} \mathrm{Lu} \mathrm{J,} \mathrm{Su} \mathrm{D,} \mathrm{Yang} \mathrm{F,} \mathrm{Zhang} \mathrm{Y,} \mathrm{Hu} \mathrm{S.}$ The advantage of chimeric antigen receptor $\mathrm{T}$ cell therapy in pediatric acute lymphoblastic leukemia with E2A-HLF fusion gene positivity: a case series. Transl Pediatr 2021;10(3):686-691. doi: $10.21037 / \mathrm{tp}-20-323$
2007;21:288-96.

4. Yeung J, Kempski H, Neat M, et al. Characterization of the $t(17 ; 19)$ translocation by gene-specific fluorescent in situ hybridization-based cytogenetics and detection of the E2A-HLF fusion transcript and protein in patients' cells. Haematologica 2006;91:422-4.

5. Glover JM, Loriaux M, Tyner JW, et al. In vitro sensitivity to dasatinib in lymphoblasts from a patient with $\mathrm{t}(17 ; 19)$ (q22;p13) gene rearrangement pre-B acute lymphoblastic leukemia. Pediatr Blood Cancer 2012;59:576-9.

6. Frismantas V, Dobay MP, Rinaldi A, et al. Ex vivo drug response profiling detects recurrent sensitivity patterns in drug-resistant acute lymphoblastic leukemia. Blood 2017;129:e26-e37.

7. Fischer U, Forster M, Rinaldi A, et al. Genomics and drug profiling of fatal TCF3-HLF-positive acute lymphoblastic leukemia identifies recurrent mutation patterns and therapeutic options. Nat Genet 2015;47:1020-9.

8. Hirai M, Yagasaki H, Fujimura J, et al. Successful preemptive donor lymphocyte infusions from a haploidentical donor in a boy with E2A-HLF-positive ALL. Leuk Lymphoma 2018;59:746-8.

9. Sun JB, Lu YY, Huang LL, et al. Characteristics of Blood Transfusion During Induction Remission in Children With Acute Lymphoblastic Leukemia: A Single-Center Retrospective Investigation. J Pediatr Hematol Oncol 2020;42:e410-5.

10. Maude SL, Frey N, Shaw PA, et al. Chimeric antigen receptor T cells for sustained remissions in leukemia. $\mathrm{N}$ Engl J Med 2014;371:1507-17.

11. de Boer J, Yeung J, Ellu J, et al. The E2A-HLF oncogenic fusion protein acts through $\mathrm{Lmo} 2$ and $\mathrm{Bcl}-2$ to immortalize hematopoietic progenitors. Leukemia 2011;25:321-30.

12. Steineck A, Wiener L, Mack JW, et al. Psychosocial care for children receiving chimeric antigen receptor (CAR) T-cell therapy. Pediatr Blood Cancer 2020;67:e28249.

13. Lee DW, Kochenderfer JN, Stetler-Stevenson M, et al. T cells expressing CD19 chimeric antigen receptors for acute lymphoblastic leukaemia in children and young adults: a phase 1 dose-escalation trial. Lancet 2015;385:517-28. 
Table S1 Change of cytokines after CAR-T therapy and the intensively supportive care in these patients

\begin{tabular}{|c|c|c|c|c|c|c|c|c|c|c|c|c|c|}
\hline & & & $\begin{array}{c}\mathrm{IL}-2 \\
(\mathrm{pg} / \mathrm{ml})\end{array}$ & $\begin{array}{c}\mathrm{IL}-4 \\
(\mathrm{pg} / \mathrm{ml})\end{array}$ & $\begin{array}{c}\mathrm{IL}-6 \\
(\mathrm{pg} / \mathrm{ml})\end{array}$ & $\begin{array}{l}\mathrm{IL}-10 \\
(\mathrm{pg} / \mathrm{ml})\end{array}$ & $\begin{array}{l}\text { TNF } \alpha \\
(\mathrm{pg} / \mathrm{ml})\end{array}$ & $\begin{array}{c}\mathrm{IFN} \\
(\mathrm{pg} / \mathrm{ml})\end{array}$ & $\begin{array}{l}\text { IL-17A } \\
(\mathrm{pg} / \mathrm{ml})\end{array}$ & Toci & GC & $\begin{array}{l}\text { Supportive } \\
\text { therapy }\end{array}$ & Adverse events \\
\hline \multirow[t]{18}{*}{ Case1 } & First & do & 0 & 1.3 & 6.7 & 5.2 & 0 & 0 & 0 & & & & fever \\
\hline & & d1 & 3.5 & 3.1 & 37.5 & 6.6 & 4 & 10 & 0 & & & & \\
\hline & & d5 & 5.9 & 0 & 23.6 & 5.2 & 2.7 & 2.8 & 0 & & & & \\
\hline & & d6 & 3.8 & 0 & 49.8 & 10.6 & 0 & 4.7 & 0 & & & & fever \\
\hline & & $\mathrm{d} 7$ & & & & & & & & & & & fever \\
\hline & & d8 & 1.8 & 0 & 19.2 & 4.2 & 2.5 & 2.6 & 0 & & & & \\
\hline & & d9 & 1.3 & 4.5 & 4.5 & 3.9 & 2.8 & 0 & 0 & & & & \\
\hline & Second & do & 1.2 & 0 & 14.7 & 0.6 & 2.6 & 4.3 & 0 & & & & fever \\
\hline & & d1 & 7.5 & 2.7 & 27.5 & 7.5 & 3.7 & 10.6 & 4 & & & & fever,chills \\
\hline & & $\mathrm{d} 2$ & 0 & 2.3 & 4.6 & 1.9 & 0 & 3.3 & 0 & & & NA & fever \\
\hline & & d3 & 3.8 & 5.8 & 15.7 & 4.2 & 4.8 & 10.5 & 2 & $80 \mathrm{mg}$ & & $\begin{array}{l}\text { albumin } \\
\text { furosemide }\end{array}$ & fever \\
\hline & & $\mathrm{d} 4$ & 7.36 & 5 & 3713.44 & 76.02 & 1.65 & 761.34 & 4.46 & $160 \mathrm{mg}$ & & NA & fever, hypotension \\
\hline & & d5 & 8.9 & 17.8 & 875.5 & 6.4 & 4.2 & 46.7 & 0 & & & $\begin{array}{l}\text { CRRT, red blood } \\
\text { cells }\end{array}$ & fever,AKI \\
\hline & & & & & & & & & & & & IVIG & \\
\hline & & d6 & 6.7 & 22 & 316 & 2.2 & 3.7 & 10.4 & 0 & & & CRRT & fever,AKI \\
\hline & & d7 & 4.3 & 12.6 & 218.6 & 3.2 & 2.6 & 12.8 & 0 & & & CRRT & fever,AKI \\
\hline & & d8 & 3.3 & 8.3 & 256.2 & 1.7 & 2.9 & 16.3 & 0 & & & & $\begin{array}{l}\text { edema of the face } \\
\text { and eyelids }\end{array}$ \\
\hline & & d9 & 0.5 & 3.2 & 143 & 13.5 & 0 & 38.4 & 5.1 & & & & \\
\hline \multirow[t]{7}{*}{ Case2 } & First & d1 & 3.1 & $<2.5$ & 9.3 & 25.7 & $<2.5$ & 5.4 & $<10$ & & & & \\
\hline & & $\mathrm{d} 2$ & $<2.5$ & $<2.5$ & 9.1 & 33.9 & 2.9 & 6.5 & 10.7 & & & & \\
\hline & & d3 & $<2.5$ & $<2.5$ & 5.4 & 24.1 & $<2.5$ & 3.3 & $<10$ & & & & \\
\hline & Second & $\mathrm{d} 4$ & $<2.5$ & $<2.5$ & 15.8 & 71 & $<2.5$ & 3.8 & $<10$ & & & & $\begin{array}{l}\text { fever, cephalalgia, } \\
\text { hands tremble }\end{array}$ \\
\hline & & d5 & 3.1 & $<2.5$ & 113.4 & 302.1 & $<2.5$ & 48.7 & $<10$ & $320 \mathrm{mg}$ & & & fever, cephalalgia \\
\hline & & d6 & $<2.5$ & $<2.5$ & 2984.2 & 420.8 & 2 & 336.9 & $<10$ & $160 \mathrm{mg}$ & & & fever \\
\hline & & $\mathrm{d} 7$ & $<2.5$ & $<2.5$ & 192.5 & 33.9 & 2.5 & 4.1 & 11.9 & & & & \\
\hline \multirow[t]{8}{*}{ Case3 } & & d0 & $<2.5$ & $<2.5$ & 21.3 & 8.6 & $<2.5$ & $<2.5$ & $<10$ & & & & fever \\
\hline & & d1 & 11.9 & $<2.5$ & 46 & 12.1 & $<2.5$ & 19.8 & $<10$ & $80 \mathrm{mg}$ & $\operatorname{dex}(3 \mathrm{mg})$ & UTI NA & $\begin{array}{c}\text { fever, eyelid swelling, } \\
\text { oliguria,weight } \\
\text { gain,chills }\end{array}$ \\
\hline & & $\mathrm{d} 2$ & 8.7 & 3.3 & 127.4 & 25.2 & 6.4 & 126.8 & $<10$ & & & $\begin{array}{l}\text { UTI,albumin } \\
\text { MAP }\end{array}$ & $\begin{array}{c}\text { fever, facial edema, } \\
\text { peritoneal and } \\
\text { pleural effusion }\end{array}$ \\
\hline & & d3 & 9.4 & 4.3 & 1650.2 & 81.8 & 2.9 & 306.6 & 13.4 & $80 \mathrm{mg}$ & $\operatorname{dex}(3 \mathrm{mg})$ & UTI, albumin fib & $\begin{array}{l}\text { fever, eyelid edema, } \\
\text { slight pericardial } \\
\text { effusion }\end{array}$ \\
\hline & & $\mathrm{d} 4$ & 12.2 & 14.2 & 5968.3 & 290.6 & 9.8 & 1637.4 & 44.3 & $160 \mathrm{mg}$ & $\begin{array}{l}\text { dex(3mg) } \\
\text { medrol } \\
(80 \mathrm{mg})\end{array}$ & $\begin{array}{c}\text { UTI,albumin, } \\
\text { fib,NA } \\
\text { phenobarbitone }\end{array}$ & $\begin{array}{c}\text { seizure } \\
\text { hytotension }\end{array}$ \\
\hline & & d5 & $<2.5$ & $<2.5$ & 1200.9 & 145.8 & $<2.5$ & 1274.4 & 14.9 & $80 \mathrm{mg}$ & & $\begin{array}{l}\text { UTI,albumin } \\
\text { plasma and fib }\end{array}$ & fever \\
\hline & & d6 & 2.9 & 4.2 & 552.5 & 18.6 & 3.7 & 67.1 & 20 & & & $\begin{array}{c}\text { UTI,albumin, } \\
\text { fib } \\
\text { PCC }\end{array}$ & \\
\hline & & $\mathrm{d} 7$ & $<2.5$ & $<2.5$ & 359.8 & 8.5 & $<2.5$ & 12.8 & $<10$ & & & UTI & \\
\hline \multirow[t]{6}{*}{ Case 4} & & d3 & 5.4 & 4.0 & 23 & 5.3 & 5.8 & 21.2 & 16.1 & & & & \\
\hline & & $\mathrm{d} 4$ & N/A & $\mathrm{N} / \mathrm{A}$ & $\mathrm{N} / \mathrm{A}$ & N/A & $\mathrm{N} / \mathrm{A}$ & N/A & $\mathrm{N} / \mathrm{A}$ & & & & fever \\
\hline & & d5 & 4.8 & 4.2 & 8.8 & 5.0 & 9.6 & 52.8 & 15 & & & & fever,chills \\
\hline & & d6 & 3.2 & 4.6 & 28.9 & 4.3 & 3.6 & 0 & 0 & & & & fever \\
\hline & & $\mathrm{d} 7$ & 3 & 3.5 & 13.7 & 3.6 & 2.7 & 0 & 0 & & & & \\
\hline & & d8 & $\mathrm{N} / \mathrm{A}$ & $\mathrm{N} / \mathrm{A}$ & N/A & N/A & $\mathrm{N} / \mathrm{A}$ & $\mathrm{N} / \mathrm{A}$ & $\mathrm{N} / \mathrm{A}$ & & & plasma & coagulopathy \\
\hline
\end{tabular}

CAR-T therapy, Chimeric Antigen Receptor (CAR) T cell thereapy; UTI, ulinastatin; dex, dexamethasone; Toci, tocilizumab; GC, glucocorticoids; NA, norepinephrine; PCC, prothrombin complex concentrate; CRRT, continuous renal replacement therapy; AKI, acute kidney injury; medrol, methylprednisolone; N/A, no detection; IVIG, intravenous immunogloblin. 